\title{
AKTIVITAS EFFECTIVE MICROORGANISMS (EM) DALAM TANAH PERTANIAN ORGANIK YANG TERPAPAR KLORPIRIFOS
}

\author{
D. Rizkiyanti ${ }^{1}$, I N. Wirajana ${ }^{1,2^{*}}$ dan I W. B. Suyasa ${ }^{1,2}$

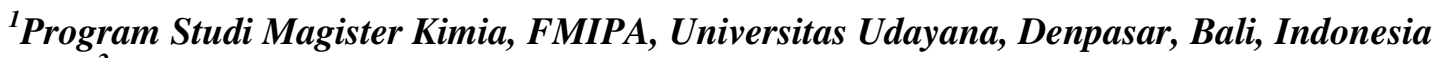 \\ ${ }^{2}$ Program Studi Kimia, FMIPA, Universitas Udayana, Badung, Bali, Indonesia \\ *Email: nengah_wirajana@unud.ac.id
}

\begin{abstract}
ABSTRAK
Salah satu cara untuk mengembalikan kesuburan tanah yang terpapar pestisida, seperti klorpirifos adalah dengan bioremediasi menggunakan Effective Microorganisms (EM). Tujuan penelitian ini adalah untuk mengetahui ketahanan mikroba EM dan aktivitas enzim pendegradasi klorpirifos dalam sampel tanah pertanian organik. Tanah pertanian organik yang digunakan sebelumnya telah terpaparEM dalam jangka waktu yang lama. Sampel tanah ini dibagi menjadi dua perlakuan, yaitu disterilkan dengan autoklaf dan tidak disterilkan (agar mikroba indigenous tetap hidup). Kedua sampel tanah ini selanjutnya ada yang tidak dan ditambahkan EM dengan waktu inkubasi 3, 5, dan 7 hari. Mikroba EM dapat bertahan terhadap paparan klorpirifos sampai konsentrasi $56 \mathrm{ppm}$. Fenomena aktivitas enzim pendegradasi klorpirifos sebesar 0,017 U/mL selama waktu inkubasi 7 hari dengan penurunan kadar klorpirifos sebesar 16,65\% ditemukan pada sampel tanah steril dengan penambahan EM. Aktivitas enzim pendegradasi klorpirofos tertinggi, yaitu sebesar 0,039 U/mL selama waktu inkubasi 3 hari, dengan penurunan kadar klorpirifos sebesar 74,11\% ditemukan pada sampel tanah tidak steril. Penurunan kadar klorpirifos tertinggi terdapat pada sampel tanah tidak steril sebesar 80,04\% dengan waktu inkubasi 5 hari.
\end{abstract}

Kata Kunci: klorpirifos, bioremediasi, mikroba EM (Effective Microorganisms)

\begin{abstract}
One way to restore soil fertility exposed to pesticides such as chlorpyrifos is by bioremediation using Effective Microorganisms (EM). The purpose of this study was to determine EM microbial resistance and chlorpyrifos degrading enzyme activity in organic farming soil sample.The organic farming soil sample used previously has been exposed to EM for a long time. This soil sample was divided into two treatments, namely sterilized by autoclaving and not sterilized (thus indigenous microbes remain alive). The next two soil samples were with and without addition of EM with incubation time of 3, 5, and 7 days. The results of this study indicated that EM microbes could withstand exposure to chlorpyrifos to a concentration of $56 \mathrm{ppm}$. The phenomenon of chlorpyrifos degrading enzyme activity was found in sterile soil samples with EM addition of $0.017 \mathrm{U} / \mathrm{mL}$ during 7-day incubation with a decrease in chlorpyrifos levels of $16.65 \%$. The highest activity of chlorpyrifos degrading enzyme was found in unsterile soil sample, which amounted to $0.039 \mathrm{U} / \mathrm{mL}$ during the 3 day incubation period with a decrease in chlorpyrifos levels of $74.11 \%$. The highest decrease in chlorpyrifos was found in unsterile soil sample by $80.04 \%$ with an incubation time of 5 days.
\end{abstract}

Keywords: chlorpyrifos, bioremediation, microbial EM (Effective Microorganisms)

\section{PENDAHULUAN}

Organofosfat merupakan jenis pestisida yang umum digunakan untuk lahan pertanian.Penggunaan pestisida secara terus menerus dapat mengakibatkan hilangnya kesuburan tanah. Organofosfat merupakan pestisida yang paling toksik diantara jenis pestisida lainnya dan sering menyebabkan keracunan pada manusia (Zulkarnain, 2010).
Salah satu pestisida golongan organofosfat yang sering digunakan adalah klorpirifos, seperti pernah ditemukan pada buah Strawberry (Fragaria ananassa rosa linda) oleh Susilawatiet al.(2016); dan pada cabai merah (Capsicum annuum L.) oleh Dewi et al. (2017).Klorpirifos mempunyai nama IUPAC [O,O-dietyl-O-(3,5,6-trichloro-2-pyridyl) phosphorothioate], dan mempunyai nama dagang Dursban, Lorsban, Dowcow, Eradex dan 
Piridane (Christensen et al., 2009).

Lingkungan tanah pertanian yang rusak akibat akumulasi pestisida dapat dikembalikan kesuburannya dengan bioremediasi. Bioremediasi adalah mekanisme biologis dari daur ulang limbah ke bentuk lain yang dapat digunakan oleh organisme lain. Mikroorganisme dapat digunakan sebagai alternatif untuk mengatasi masalah pencemaran lingkungan. Enzim-enzim yang diproduksi oleh mikroorganisme memodifikasi polutan beracun dengan mengubah struktur kimia polutan, proses ini disebut biotransformasi. Umumnya biotransformasi berujung pada biodegradasi, polutan beracun terdegradasi kemudian strukturnya menjadi tidak kompleks, dan akhirnya menjadi bahan yang mempunyai tingkat toksisitas rendah (Vidali, 2001).

Penelitian sebelumnya telah melaporkan mikroorganisme yang dapat mendegradasi klorpirifos. Misalnya Pseudomonas sp. mampu mendegradasi klorpirifos sebesar 94\% dalam 18 hari (Farhan et al., 2012), Achromobacter xylosoxidans dan Ochrobactrum sp. mampu menurunkan kadar klorpirifos sebesar 93-100\% dari konsentrasi awal $200 \mathrm{ppm}$ dalam 42 hari (Akbar and Sultan, 2016). Effective Microorganisms (EM) merupakan produk yang memiliki kandungan kelompok mikroba fotosintetik. Mikroba jenis ini merupakan salah satu spesies mikroba yang diduga memiliki kemampuan mereduksi pestisida. Bhagobaty and Malik (2008) menyebutkan bahwa Pseudomonas sp., salah satu contoh mikroba fotosintetik, dapat tumbuh pada media kultur yang mengandung klorpirifos dengan konsentrasi 25-300 mg/L. EM merupakan konsorsium mikroba dari gabungan spesies mikroba efektif yang telah teruji, antara lain Lactobacillus casei, Saccharomyces cerevisiae, Rhodopseudomonas palustris, dan spesies mikroba fotosintetik lainnya.

EM bekerja secara alamiah dengan merangsang aktivitas biologis di dalam tanah, proses tersebut dapat meningkatkan kualitas tanah dengan meningkatkan proses pemupukan alami di dalam tanah. EM tidak hanya menambah populasi mikroba dalam tanah tetapi juga akan merangsang mikroba indigenous. Stimulasi ini dapat menyebabkan peningkatan kapasitas fiksasi nitrogen secara langsung melalui peningkatan bakteri pengikat nitrogen (Sangakkara, 2002). EM dapat diaplikasikan pada beberapa bidang. Pemakaian EM meliputi bidang pertanian, peternakan, perkebunan, pengkomposan, pembersihan septic tank, kontrol alga dan sebagainya (Higa and Chinen, 1998). Pada penelitian ini telah dilakukan studi ketahanan mikroba EM dalam tanah pertanian organik yang terpapar klorpirifos. Peranan EM juga dipelajari dengan menguji adanya fenomena aktivitas enzim pendegradasi klorpirifos dalam sampel tanah pertanian organikyang sebelumnya telah terpapar EM dalam jangka waktu yang lama.

\section{MATERI DAN METODE}

\section{Bahan dan Peralatan}

Bahan yang digunakan dalam penelitian ini adalah Effective Microorganisms (EM) merek EM4, tanah pertanian organik yang telah terpapar EM dalam jangka waktu yang lama (dengan dan tanpa disterilkan menggunakan autoklaf),plate count agar (PCA), peptone water, klorpirifos, aquades, n-heksana, natrium sulfat anhidrat, natrium klorida.

\section{Peralatan}

Alat-alat yang digunakan dalam penelitian ini adalah Erlenmeyer, gelas Beaker, pipet volume, pipet mikro $0,5-10 \mu \mathrm{L}, 10-100$ $\mu \mathrm{L}$, dan 100-1000 $\mu \mathrm{L}$, pipet tetes, cawan pisah, batang pengaduk, kawat ose, cawan petri, bunsen, sumbat kasa, ball filler, labu ukur, thermometer, pipet mikro, tip mikro pipet, penangas air, botol semprot, stirer, gunting, tissue, kertas untuk menimbang, label, botol kaca $40 \mathrm{~mL}$,aluminium foil, inkubator merk BINDER, spektrofotometer UV-Vis singlebeam GENESYS 10S, timbangan digital tipe DIGI SEIKO DS-561, autoklaf merek LABO LDA-50 SS, Laminar air flow (LAF) dan shaker model VRN-200.

\section{Cara Kerja \\ Uji pertumbuhan mikroba EM terhadap insektisida klorpirifos.}

Sebanyak 4,7 gram plate count agar (PCA) dilarutkan dengan aquades sebanyak 200 $\mathrm{mL}$ dipanaskan dan disterilkan dengan autoklaf. PCA steril dituang ke dalam cawan petri dengan perlakuan sebagai berikut: media kontrol negatif; penambahan mikroba EM sebanyak 1 $\mathrm{mL}$; penambahan mikroba EM sebanyak $1 \mathrm{~mL}$ dan larutan klorpirifos 0,1 ppm dalam molase 1 $\mathrm{mL}$; dan penambahan mikroba EM sebanyak 1 $\mathrm{mL}$ dan larutan klorpirifos 0,01 ppm dalam molase $1 \mathrm{~mL}$. Sampel didiamkan hingga media agar mengeras, kemudian sampel diinkubasi ke 
dalam inkubator selama 2 hari pada suhu $37^{\circ} \mathrm{C}$. Sampel diobservasi setiap 3 jam sekali.

\section{Uji ketahanan mikroba EM terhadap penambahan insektisida klorpirifos}

Sebanyak $250 \mathrm{~mL}$ air dan $250 \mathrm{~mL}$ peptone water yang telah steril dimasukkan ke dalam masing-masing 5 buah Erlenmeyer 100 $\mathrm{mL}$.Sebanyak 5 buah sampel air dan 5 buah sampel peptone water ditutup dengan sumbat kasa kemudian dimasukkan ke dalam autoklaf selama 15 menit dengan suhu $121^{\circ} \mathrm{C}$. Masingmasing sampel ditambah dengan mikroba EM sebanyak $1 \mathrm{~mL}$ dan klorpirifos 0,$01 ; 0,1$; dan 1 $\mathrm{mL}$. Semua sampel dishaker dengan kecepatan $150 \mathrm{rpm}$ dan diinkubasi pada suhu ruang selama 3, 5, dan 7 hari. Sampel yang telah diinkubasi diuji dengan uji gores pada media PCA padat, kemudian diinkubasi kembali dalam inkubator dengan suhu $37^{\circ} \mathrm{C}$ selama 2 hari.

\section{Preparasi dan inkubasi sampel}

Sampel tanah pertanian organik yang telah terpapar EM diayak dengan ayakan 90 mesh untuk memisahkan tanah dengan kerikil dan batu kemudian ditimbang sebanyak 200 gram. Sampel tanah yang telah diayak dibagi menjadi 2 bagian dengan masing-masing perlakuan disteril dalam autoklaf untuk disterilisasi selama 15 menit dengan suhu $121^{\circ} \mathrm{C}$ dan tidak steril. Masing-masing sampel berisi tanah seberat 50 gram ditambah dengan klorpirifos merk Dursban sebanyak 0,01 mL dengan konsentrasi $200 \mathrm{~g} / \mathrm{L}$. Kadar klorpirifos yang ditambahkan dibawah standar baku mutu residu klorpirifos dalam tanah (kadar baku mutu residu klorpirifos pada tanah pertanian 0,05 ppm). Sampel tersebut ditambah dengan konsorsium mikroba EM sebanyak $1 \mathrm{~mL}$. sehingga variasi perlakuan sampel menjadi : Tanah steril + klorpirifos $10 \mu \mathrm{L} \mathrm{mL}+$ EM $1 \mathrm{~mL}$; tanah steril + klorpirifos $10 \mu \mathrm{L}$; tanah tidak steril + klorpirifos $10 \mu \mathrm{L}+$ EM $1 \mathrm{~mL}$; dan tanah tidak steril + klorpirifos $10 \mu \mathrm{L}$. Sampel tanah ditambah dengan akuades steril sebanyak $50 \mathrm{~mL}$ agar sampel dapat diaduk dengan shaker.
Selanjutnya semua sampel tersebut diinkubasi pada suhu ruang, ditutup dengansumbat kasa dan dikocok dengan shaker dengan kecepatan 150 rpm selama 3, 5 dan 7 hari. Setelah sampel selesai diinkubasi dilakukan ekstraksi klorpirifos serta analisis penentuan konsentrasi klorpirifos dan pengujian aktivitas enzim pendegradasinya dalam tanah. Sampel tanah diberi kode untuk memudahkan pembacaan. Sampel digores pada media PCA kemudian diinkubasi selama 2 hari untuk mengetahui ketahanan mikroba EM (Effective Microorganisms) dalam tanah pertanian organik yang terpapar klorpirifos.

\section{Analisis konsentrasi residu klorpirifos}

Analisis konsentrasi residu klorpirifos dalam tanah ditentukan secara spektrofotometri UV-Vis. Pertama dilakukan preparasi larutan standar stok klorpirifos 500 ppm disiapkan dalam n-heksana. Larutan standar kerja disiapkan dengan pengenceran larutan stok dengan n-heksana untuk mendapatkan rentang konsentrasi $0,10,15,20,25$, dan $30 \mathrm{ppm}$. Penentuan panjang gelombang maksimum dilakukan pada rentang $200-350 \mathrm{~nm}$ menggunakan n-heksana sebagai blanko. Konsentrasi klorpirifos 0 ppm tersebut disiapkan berfungsi sebagai larutan blanko. Karena konsentrasi klorpirifos yang digunakan cukup rendah maka penentuan konsentrasi residu klorpirifos dalam tanah dilakukan menggunakan metode adisi standar.

\section{Pengukuran aktivitas enzim}

Pengukuran aktivitas enzim pendegradasi klorpirifos dalam tanah dilakukan dengan menentukan kecepatan pengurangan residu klorpirifos dalam tanah sebagai substrat enzim. Satu unit (U) aktivitas enzim pendegradasi klorpirifos dalam tanah adalah jumlah enzim yang dibutuhkan untuk mendegradasi 1 (satu) $\mu$ mol klorpirifos per hari pada kondisi percobaan dengan perhitungan menggunakan rumus di bawah ini.

Keterangan :

$$
\text { Aktivitas enzim }\left(\frac{\mathrm{U}}{\mathrm{mL}}\right)=\frac{(\mathrm{X}-\mathrm{Y}) \mathrm{x} \text { FP }}{\text { Waktu Inkubasi x BM klorpirifos }}
$$

$\mathrm{X}=$ konsentrasi klorpirifos dalam sampel (ppm) sebelum inkubasi (awal)

$\mathrm{Y}=$ konsentrasi klorpirifos dalam sampel (ppm) setelah inkubasi (akhir)

$\mathrm{FP}=$ faktor pengenceran saat pengukuran

Waktu inkubasi $=3,5$, dan 7 hari

$\mathrm{BM}=$ adalah berat molekul klorpirifos $(359,59 \mathrm{~g} / \mathrm{mol})$. 


\section{HASIL DAN PEMBAHASAN}

\section{Pertumbuhan Mikroba EM dalam Media Mengandung Klorpirifos}

Media PCA tanpa penambahan EM dan klorpirifos digunakan sebagai kontrol negatif (A).Media PCA dengan penambahan mikroba EM tanpa penambahan klorpirifos digunakan sebagai kontrol positif (B). Media PCA lainnya ditambahkan konsorsium mikroba EM dengan klorpirifos $0,1 \mathrm{ppm}(\mathrm{C})$, dan konsorsium mikroba EM dengan klorpirifos 0,01 ppm (D). Semua sampel diinkubasi pada suhu $37^{\circ} \mathrm{C}$ selama dua hari dan hasilnya diobservasi setiap 3 jam sekali. Setiap proses dikerjakan secara aseptis dan steril. Perbandingan pertumbuhan mikroba dalam berbagai kondisi tersebut dapat dilihat pada Gambar 1.

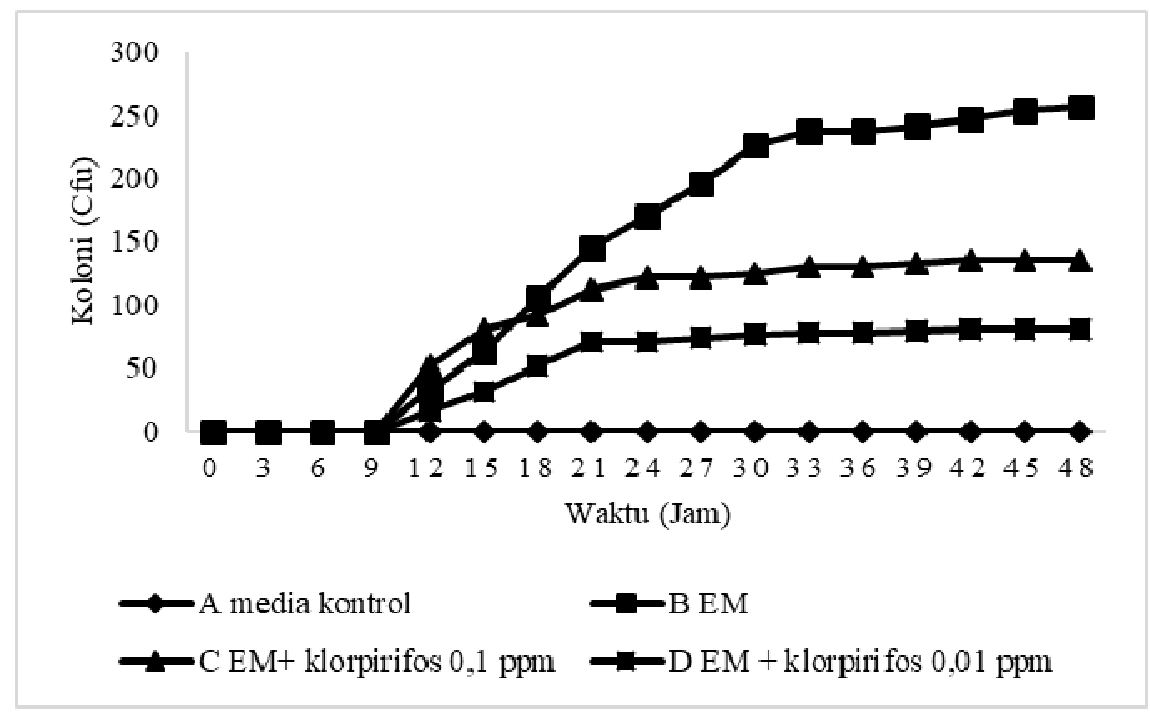

Gambar 1. Kurva perbandingan pertumbuhan mikroba.

Dalam media PCA (A) yang berfungsi sebagai kontrol negatif tidak teramati pertumbuhan mikroba yang menunjukkan tidak ada kontaminasi. Media yang ditambah konsorsium mikroba EM (B) menunjukkan kecepatan pertumbuhan mikroba fase log tertinggi dibandingkan dengan mikroba pada media lainnya. Mikroba ini dapat terus tumbuh tanpa adanya hambatan dari klorpirifos. Media yang berisi konsorsium mikroba EM dengan klorpirifos 0,1 ppm (C) menunjukkan kecepatan pertumbuhan lebih tinggi jika dibandingkan dengan media yang berisi konsorsium mikroba EM dengan klorpirifos $0,01 \quad \mathrm{ppm}$ (D). Kandungan klorpirifos dalam media (C dan D) dapat menghambat pertumbuhan mikroba. Sampel dengan penambahan klorpirifos menunjukkan bahwa pada titik tertentu mikroba berhenti tumbuh karena masa adaptasi dengan lingkungan tercemar klorpirifos. Mikroba yang mampu beradaptasi dengan lingkungan tercemar klorpirifos tumbuh kembali yang menandakan bahwa mikroba mampu memanfaatkan insektisida tersebut untuk proses metabolisme. Sampel dengan kadar klorpirifos 0,1 ppm lebih cepat fase pertumbuhannya dibandingkan sampel dengan kadar klorpirifos sebesar 0,01 ppm karena mikroba EM dapat memanfaatkan klorpirifos sebagai sumber karbon.

\section{Ketahanan Mikroba EM terhadap Paparan Klorpirifos}

Media yang digunakan pada uji ketahanan mikroba terhadap klorpirifos yaitu air dan pepton.Pepton merupakan hidrolisat protein yang berasal dari reaksi hidrolisis protein oleh protease. Tujuan penggunaan pepton adalah sebagai sumber nitrogen agar mikroba dapat tumbuh dengan baik. Media air tanpa penambahan pepton juga digunakan untuk mengetahui kemampuan mikroba bertahan hidup tanpa adanya sumber nutrien lainnya selain klorpirifos. Data pengujian kemampuan mikroba beradaptasi dalam variasi penambahan insektisida klorpirifos dapat dilihat pada Tabel 1. 
Tabel 1. Ketahanan mikroba EM beradaptasi dalam variasi penambahan klorpirifos

\begin{tabular}{clc}
\hline No & \multicolumn{1}{c}{ Media } & Hasil \\
\hline 1 & Air sebagai kontrol negatif & $(-)$ \\
2 & Air + EM sebagai kontrol positif & $(+)$ \\
3 & Klorpirifos dalam air $(56 \mathrm{ppm})+\mathrm{EM}$ & $(+)$ \\
4 & Klorpirifos dalam air $(560 \mathrm{ppm})+\mathrm{EM}$ & $(-)$ \\
5 & Klorpirifos dalam air $(5600 \mathrm{ppm})+\mathrm{EM}$ & $(-)$ \\
6 & Pepton sebagai kontrol negative & $(-)$ \\
7 & Pepton + EM sebagai kontrol positif & $(+)$ \\
8 & Klorpirifos dalam pepton $(56 \mathrm{ppm})+\mathrm{EM}$ & $(+)$ \\
9 & Klorpirifos dalam pepton $(560 \mathrm{ppm})+\mathrm{EM}$ & $(-)$ \\
10 & Klorpirifos dalam pepton $(5600 \mathrm{ppm})+\mathrm{EM}$ & $(-)$ \\
\hline
\end{tabular}

Keterangan : (-) tidak tumbuh dan (+) tumbuh.

Data pada Tabel 1 menunjukkan bahwa mikroba EM masih dapat bertahan hidup pada konsentrasi klorpirifos sebesar 56 ppm, baik dalam media air maupun pepton. Hasil ini mengindikasikan bahwa mikroba EM masih bertahan hidup tanpa adanya sumber nutrien lainya selain klorpirifos. Pada konsentrasi klorpirifos 560 dan 5600 ppm, mikroba EM tidak dapat bertahan hidup yang ditunjukkan olehtidak adanya koloni mikroba yang teramati pada media padat setelah uji gores. Hasil ini mengindikasikan bahwa konsentrasi tersebut telah melewati ambang batas toksisitasnya.

\section{Ketahanan Mikroba EM dalam Tanah Pertanian Organik yang Terpapar Klorpirifos}

Hasil uji gores pada media padat PCA setelah inkubasi 3, 5, dan 7 hari menunjukkan pola yang relatif sama. Kontrol negatif untuk media pada PCA tidak teramati adanya mikroba yang tumbuh, Hasil ini menunjukkan tidak adanya kontaminasi pada saat dilakukan uji gores. Namun hasil uji gores dari tanah steril dengan penambahan klorpirifos menunjukkan adanya sedikit pertumbuhan mikroba, yang mengindikasikan adanya kontaminasi. Sampel tanah steril dengan penambahan mikroba EM dan klorpirifos menunjukkan jumlah pertumbuhan mikroba yang lebih banyak jika dibandingkan dengan sampel tanah steril dengan klorpirifos saja, karena mikroba EM mampu bertahan selama masa inkubasi.Data tersebut dapat dilihat pada Tabel 2 .

Tabel 2. Ketahanan mikroba EM (Effective Microorganisms) dalam tanah pertanian organik yang terpapar klorpirifos

\begin{tabular}{clc}
\hline No & \multicolumn{1}{c}{ Sampel } & Hasil \\
\hline Inkubasi 3 hari & \\
\hline 1 & PCA & $(-)$ \\
2 & Tanah Steril + Klorpirifos & $(+)$ \\
3 & Tanah Steril + EM + Klorpirifos & $(++)$ \\
4 & Tanah Tidak Steril + Klorpirifos & $(+++)$ \\
5 & Tanah Tidak Steril + EM + Klorpirifos & $(+++)$ \\
\hline Inkubasi 5 hari & $(-)$ \\
\hline 6 & PCA & $(+)$ \\
7 & Tanah Steril + Klorpirifos & $(++)$ \\
8 & Tanah Steril + EM + Klorpirifos & $(+++)$ \\
9 & Tanah Tidak Steril + Klorpirifos & $(+++)$ \\
10 & Tanah Tidak Steril + EM + Klorpirifos &
\end{tabular}




\begin{tabular}{clc}
\hline Inkubasi 7 hari & \\
\hline 11 & PCA & $(-)$ \\
12 & Tanah Steril + Klorpirifos & $(+)$ \\
13 & Tanah Steril + EM + Klorpirifos & $(++)$ \\
14 & Tanah Tidak Steril + Klorpirifos & $(+++)$ \\
15 & Tanah Tidak Steril + EM + Klorpirifos & $(+++)$ \\
\hline &
\end{tabular}

Sampel tanah yang tidak steril dengan penambahan klorpirifos menunjukkan adanya pertumbuhan mikroba pada uji gores di media padat, baik waktu inkubasi 3, 5, maupun 7 hari. Hasil ini menunjukkan adanya mikroba indigenous dari tanah pertanian organik yang mampu bertahan hidup dalam lingkungan yang terpapar klorpirifos. Hasil uji gores untuk sampel tanah tidak steril dengan penambahan klorpirifos menunjukkan jumlah pertumbuhan mikroba yang lebih banyak dibandingkan dengan sampel tanah steril dengan penambahan mikroba EM dan klorpirifos. Data ini mengindikasikan bahwa mikroba indigenous yang ada dalam tanah pertanian organik menunjukkan ketahanan yang lebih tinggi dibandingkan mikroba EM. Indikasi ini diperkuat olehdata lainnya, yaitu hasil uji gores untuk sampel tanah tidak steril dengan penambahan klorpirifos dibandingkan dengan hasil uji gores untuk sampel tanah tidak steril dengan penambahan mikroba EM dan klorpirifos yang menunjukkan jumlah koloni atau pertumbuhan mikroba yang sama, baik waktu inkubasi 3dan5, maupun 7 hari.

\section{Aktivitas Enzim Pendegradasi Klorpirifos}

Konsentrasi klorpirifos yang diperoleh dari masa inkubasi 3 hingga 7 hari dibandingkan untuk mengetahui hubungan antara konsentasi dan waktu. Adapun kurva perbandingan waktu inkubasi 3, 5 dan 7 hari terhadap konsentarsi klorpirifos dapat dilihat pada Gambar 2.

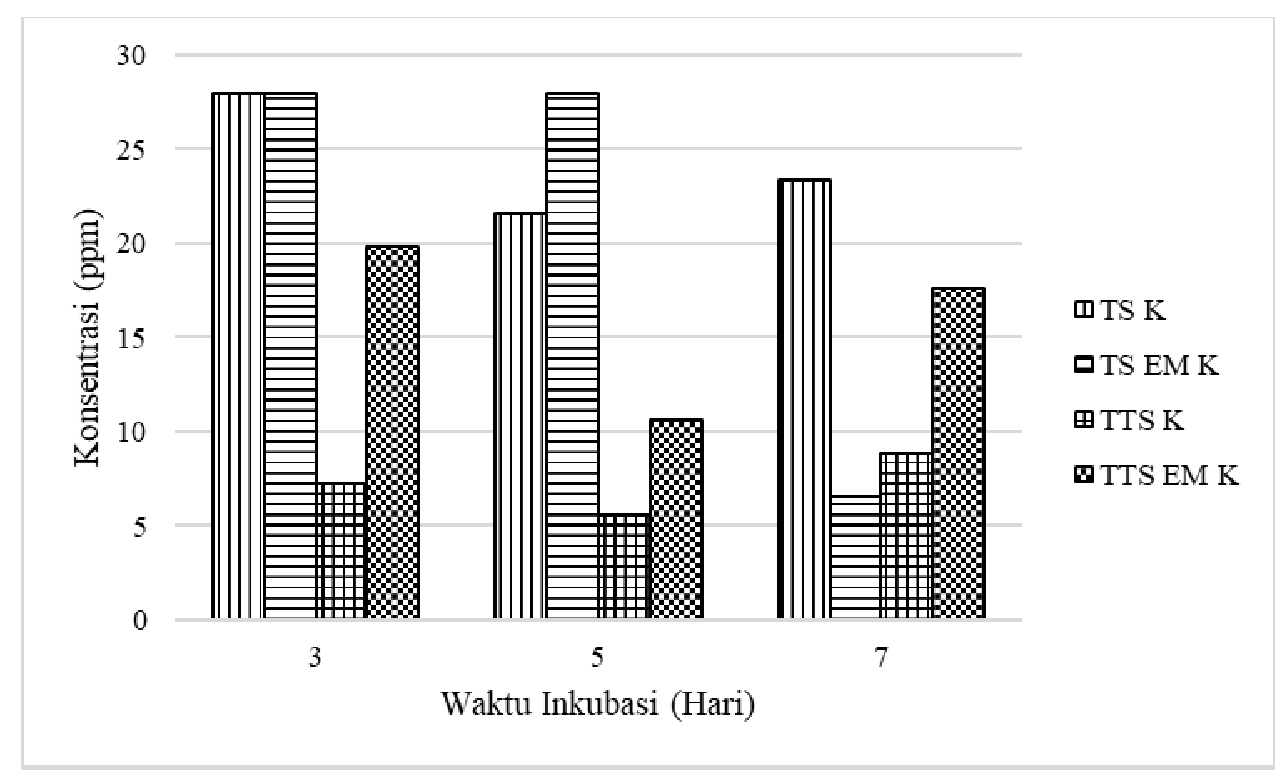

Gambar 2. Diagram perbandingan konsentrasi klorpirifosterhadap waktu inkubasi.

Secara umum terjadi penurunan konsentrasi klorpirifos pada sampel tanah tidak steril dengan dan tanpa penambahan mikroba EM, pada waktu inkubasi 3, 5, dan 7 hari. Konsentrasi klorpirifos sampel tanah tidak steril tanpa penambahan mikroba EM turun dari 28 ppm menjadi 7,25 ppm setelah 3 hari; $5,59 \mathrm{ppm}$ setelah 5 hari; dan 8,83 ppm setelah 7 hari; atau persentase penurunan berturut-turut sebesar $74,11 \%$ setelah 3 hari; $80,04 \%$ setelah 5 hari; 
dan 68,45 \% setelah 7 hari. Hasil ini menunjukkan bahwa mikroba indigenous mampu mendegradasi klorpirifos dengan cukup signifikan. Namun fenomena unik ditemukan pada sampel tanah tidak steril dengan penambahan mikroba EM, yang mana penurunan konsentrasi klorpirifos lebih kecil, yaitu turun dari 28 ppm menjadi 19,83 ppm setelah 3 hari; 10,62 ppm setelah 5 hari; dan 17,58 ppm setelah 7 hari; atau persentase penurunan berturut-turut sebesar 29,18\% setelah 3 hari; $62,07 \%$ setelah 5 hari; dan 37,23\% setelah 7 hari. Fakta ini masih sulit untuk dijelaskan, dugaan sementara kemungkinan karena adanya penambahan mikroba EM ke dalam tanah pertanian organik yang sudah sebelumnya mengandung mikroba indigenous menyebabkan penurunan kemampuan adaptasi terhadap polutan klorpirifos.Konsorsium mikroba dapat bekerja secara kompleks.Keberadaan beberapa jenis mikroba yang berbeda dapat menyebabkan terjadinya symbiosis tertentu, misalnya hasil metabolisme mikroba EM mampu dimanfaatkan untuk metabolisme mikroba indigenus. Selain itu jenis mikroba lain juga memungkinkan untuk menghambat proses metabolisme untuk menurunkan kadar klorpirifos, sehingga pada sampel dengan perlakuan yang sama dapat diperoleh hasil yang berbeda. Fenomena ini menarik untuk diteliti lebih lanjut yaitu mengenaispesies mikroba yang berperan dan jenis enzimnya.

Penurunan konsentrasi klorpirifos pada sampel tanah tidak steril diduga mikroba EM tidak hanya menambah populasi mikroba dalam tanah tetapi juga akan merangsang mikroba indigenous. Stimulasi ini dapat menyebabkan peningkatan kapasitas fiksasi nitrogen secara langsung melalui peningkatan bakteri pengikat nitrogen.Penurunan dapat terjadi karena adsorpsi dalam tanah, peran mikroba indigenous dari tanah itu sendiri dan penambahan mikroba dari luar memerlukan waktu untuk beradaptasi dalam lingkungan yang toksik (Sangakkara, 2002).
Penurunan konsentrasi klorpirifos pada sampel tanah steril dengan penambahan mikroba EM terjadi pada waktu inkubasi 7 hari.Hasil ini mengindikasikan bahwa mikroba EM perlu waktu adaptasi sampai 7 hari untuk memanfaatkan klorpirifos sebagai sumber energi untuk bertahan hidup.Namun hasil ini masih perlu diteliti lebih lanjut karena beberapa data yang ditunjukkan untuk mendukung dugaan ini belum terdeteksi.Hal ini disebabkan karena metode ekstraksi klorpirifos dari tanah belummenunjukkan data yang konsisten, sehingga perlu dilakukan penelitian lebih lanjut.Namun dari data di atas telah mengindikasikan bahwa penurunan konsentrasi klorpirifos karena adanya aktivitas mikroba. Penurunan konsentrasi klorpirifos pada sampel tanah steril diduga karena faktor adsorpsi dari tanah dan faktor lainnya. Hasil penentuan konsentrasi klorpirifos dalam tanah steril menunjukkan penurunan yang lebih sedikit, dari 28 ppm menjadi 23,34 ppm setelah 7 hari atau persentase penurunan sebesar $16,65 \%$ setelah 7 hari.

$\begin{array}{crr}\text { Penurunan } & \text { konsentrasi } & \text { klorpirifos } \\ \text { disebabkan adanya aktivitas } & \text { mikroba }\end{array}$ pendegradasi, baik dari mikroba indigenous maupun mikroba EM.Pada penelitian ini belum dilakukan isolasi mikroba yang memiliki kemampuan tersebut.Namun enzim yang dikeluarkan oleh mikroba tersebut ditentukan aktivitas enzimnya. Degradasi secara biokimia senyawa organofosfat seperti klorpirifos karena adanya aktivitas enzim yang identik dari beberapa mikroba yang telah ditemukan, yaitu organofosfat hidrolase atau fosfotriesterase (Singh and Walker, 2006). Aktivitas enzim yang ditentukan adalah kecepatan pengurangan konsentrasi klorpirifos dari hari ke 0 hingga ke 7, dilambangkan dengan kode aktivitas enzim t0t3, t0-t5, dan t0-t7. Data aktivitas enzim pendegradasi klorpirifos selama masa inkubasi dapat dilihat pada Tabel 4. 
Tabel 4. Aktivitas enzim pendegradasi klorpirifos pada $\mathrm{t} 0-\mathrm{t} 3$, $\mathrm{t} 0-\mathrm{t} 5$, dan $\mathrm{t} 0-\mathrm{t} 7$

\begin{tabular}{cccc}
\hline Sampel & $\begin{array}{c}\text { Aktivitas } \\
\text { Enzim } \\
(\mathbf{U} / \mathbf{m L}) \\
\mathbf{t 0 - t 3}\end{array}$ & $\begin{array}{c}\text { Aktivitas } \\
\text { Enzim } \\
(\mathbf{U} / \mathbf{m L}) \\
\mathbf{t 0 - t 5}\end{array}$ & $\begin{array}{c}\text { Aktivitas } \\
\text { Enzim } \\
(\mathbf{U} / \mathbf{m L}) \\
\mathbf{t 0 - t 7}\end{array}$ \\
\hline TS EM K & 0 & 0 & 0,017 \\
TTS K & $\mathbf{0 , 0 3 9}$ & 0,025 & 0,015 \\
TTS EM K & 0,015 & 0,019 & 0,008 \\
\hline
\end{tabular}

Aktivitas enzim pendegradasi klorpirifos tertinggi ditunjukkan pada sampel tanah tidak steril yang tidak ditambahimikroba EM (TTS K) pada t0-t3, yaitu sebesar $0,039 \mathrm{U} / \mathrm{mL}$. Hal ini menunjukkan pada waktu inkubasi 3 hari, mikroba indigenous memproduksi enzim pendegradasi klorpirifos tertinggi. Penelitian ini membuktikan bahwa mikroba indigenous berperan penting dalam bioremediasi.Enzim pendegradasi klorpirifos yang dihasilkan olehmikroba EM terdeteksi aktivitasnya selama inkubasi 7 hari (t0-t7), yaitu sebesar 0,017U/mL.Walaupun aktivitasnya lebih kecil dari aktivitas enzim dari mikroba indigenous, namun menarik untuk diteliti lebih lanjut untuk mengetahui mikroba dan enzim yang berperan dalam degradasi klorpirifos. Mikroba indigenous mampu beradaptasi dalam lingkungan yang berbeda seperti konsentrasi klorpirifos, sumber karbon, pH mampu menurunkan kadar klorpirifos sebesar 94\% dengan konsentrasi 400 ppm dalam masa inkubasi 18 hari (Farhan et al., 2012).

\section{SIMPULAN}

Mikroba EM (Effective Microorganisms) dapat bertahan dalam tanah pertanian organik yang terpapar klorpirifos.Terdapat fenomena aktivitas enzim pendegradasi klorpirifos yang dihasilkan dari mikroba EM yang dapat menurunkan kadar klorpirifos.

\section{UCAPAN TERIMA KASIH}

Ucapan terima kasih disampaikan kepada PT. Karya Pak Oles Tokcer, Denpasar dan Laboratorium UPT Forensik Sains Universitas Udayana, Jimbaran, yang telah memberikan fasilitas untuk pelaksanaan penelitian ini.

\section{DAFTAR PUSTAKA}

Akbar, S. and Sultan, S. 2016. Soil Bacteria Showing a Potential of Chlorpyrifos Degradation and Plant Growth Enchancement. Brazilian Journal of Microbiology. 47(3): 563-570.

Dewi, I G.A.S.U., Mahardika, I G. dan Antara, M. 2017. Residu Pestisida Golongan Organofosfat Komoditas Buah Cabai Merah (Capsicum annuum L.) pada Berbagai Lama Penyimpanan. Ecotrophic 11 (1): 34-39.

Farhan, M., Khan, A. U., Wahid, A. and Ahmad, M. 2012. Biodegradation of Chlorpyrifos Using Indugenous Pseudomonas sp. Isolated from Industrial Drain. Pakistan Journal of Nutrition. 11(12): 1183-1189.

Sangakkara, U.R. 2002. The Technology of Effective Microorganisms Case Studies of Application. Research Activities Cirencester. Royal Agricultural College, Cirencester : United Kingdom.

Singh, B.K. and Walker, A. 2006. Microbial Degradation of Organophosphorus Compounds. FEMS Microbial Rev. 30: 428-471.

Susilawati, NP. A., Suprihatin, I.E. dan Suastuti, NG.A.M.D.A. 2016. Analisis Residu Pestisida Organofosfat pada Buah Strawberry (Fragaria ananassa rosalinda) Menggunakan Kromatografi Gas.Cakra Kimia. (4) 1: 18-23.

Vidali, M. 2001. Bioremediation AnOverview, Pure Appl. Chem. (73): 1163- 1172.

Zulkarnain, I. 2010. Aplikasi Pestisida dan Analisa Residu Pestisida Golongan Organofosfatpada Beras di Kecamatan Portibi Kabupaten Padang Lawas Utara. Skripsi. Medan: Universitas Sumatra Utara. 